\title{
OPTIMASI LOKASI POS PEMADAM KEBAKARAN DI KABUPATEN SITUBONDO MENGGUNAKAN PEMROGRAMAN LINIER
}

\author{
Asmul Faisi1) \\ Darsih Idayani2) \\ Yesi Puspitasari1) \\ 1)Program Studi Pendidikan Matematika STKIP PGRI Situbondo \\ 2)Universitas Terbuka \\ e-mail: zymul@ymail.com
}

\begin{abstract}
Optimization of fire station location is carried out to determine the optimal location of the fire station to obtain efficiency and effectiveness in handling fire incidents. In this research, the optimization problem of the fire station location's in Situbondo District is solved by a linear programming model with a minimization objective function, i.e to minimize costs. The constraints are travel time and non-negative constraints. The model was solved using the simplex method by MPL (Mathematical Programming Language) software. The minimization objective function is chosen to obtain minimal costs due to the minimal number of fire stations. The result is there should be two fire stations in Situbondo District, i.e Banyuglugur and Arjasa Sub-Districts which is indicated by the optimization results $x_{3}=x_{14}=1$ and objective function $z_{\min }=2$.
\end{abstract}

Keywords: linear programming, simplex, MPL

\begin{abstract}
ABSTRAK
Optimasi lokasi pemadam kebakaran dilakukan untuk menentukan lokasi pos pemadam kebakaran yang optimal sehingga menghasilkan efisiensi dan efektivitas dalam melakukan penanganan kejadian kebakaran. Dalam penelitian ini, permasalahan optimasi lokasi pos pemadam kebakaran di Kabupaten Situbondo diselesaikan dengan menggunakan model pemrograman linier dengan fungsi tujuan minimasi, yaitu meminimalkan biaya. Kendala yang digunakan adalah kendala waktu tempuh dan kendala non-negatif. Model tersebut diselesaikan menggunakan metode simpleks menggunakan bantuan software MPL (Mathematical Programming Language). Fungsi tujuan minimasi dipilih untuk mendapatkan jumlah pos pemadam kebakaran yang paling sedikit sehingga biaya yang dikeluarkan sedikit. Hasilnya adalah pos pemadam kebakaran di Kabupaten Situbondo seharusnya ada dua, yaitu di Kecamatan Banyuglugur dan Kecamatan Arjasa yang ditunjukkan dengan hasil optimasi $\mathrm{x}_{3}=\mathrm{x}_{14}=1$ dan fungsi objektif $z_{\min }=2$.

Kata kunci: pemrograman linier, simpleks, MPL

Berdasarkan data UPT Pemadam Kebakaran dan Penyelamatan Kabupaten Situbondo menunjukkan bahwa pada tahun 2019 jumlah kebakaran di Kabupaten Situbondo semakin meningkat. Pemerintah Kabupaten Situbondo telah berusaha melayani pengaduan kebakaran dari
\end{abstract}


penduduk Kabupaten Situbondo dengan sebaik-baiknya. Hal ini dapat dibuktikan dengan tersedianya fasilitas yang lengkap dengan mobil pemadam kebakaran sebanyak 7 unit yang tersebar di tiga pos pemadam kebakaran.

Namun untuk mengatasi kebakaran agar teratasi dengan cepat, tidak hanya ditentukan oleh tersedianya fasilitas mobil pemadam kebakaran, tetapi juga ketepatan dan kecepatan mobil pemadam kebakaran sampai di lokasi kejadian. Apabila jumlah dan lokasi pos pemadam kebakaran tidak sebanding dengan kebutuhan akan pelayanannya maka akan mengakibatkan banyaknya jumlah kasus kebakaran terjadi yang mengakibatkan api membakar isi bangunan dan sekitarnya sebelum pasukan pemadam tiba di lokasi. Oleh karena itu, optimasi lokasi pemadam kebakaran perlu dilakukan untuk mendapatkan lokasi pos pemadam kebakaran yang tepat dengan jumlah yang pas sehingga menghasilkan efisiensi dan efektivitas dalam melakukan penanganan kejadian kebakaran.

Penelitian terkait pemilihan lokasi optimal telah banyak dilakukan, diantaranya adalah sebagai berikut. Jasriadi $d k k$ (2015) menganalisis lokasi dan jumlah pos pemadam kebakaran menggunakan GIS (Geographic Information System) (Jasriadi et al., 2015). Febrianto dan Siswanto (2020) menggunakan MILP (Mixed Integer Linear Programming) untuk mengevaluasi lokasi dan jumlah gudang PT Petrokimia Gresik untuk menyimpan persediaan pengaman. Dalam penelitian tersebut disimpulkan bahwa MILP adalah metode optimal untuk evaluasi tersebut karena sesuai dengan karakter dan kondisi sistem distribusi di PT Petrokimia Gresik (Febrianto \& Siswanto, 2020). Idayani $d k k$ (2020) menggunakan model set covering problem dalam menentukan lokasi dan jumlah pos pemadam kebakaran untuk meminimalkan biaya pembangunan pos pemadam kebakaran (Idayani et al., 2020). Hasan dan Kadhim (2020) menentukan lokasi optimal untuk pelayanan kesehatan darurat di Kota Najaf menggunakan fuzzy dan integer programming (Hasan \& Kadhim, 2020). Idayani $d k k$ (2021) menggunakan model maximal covering problem dalam memaksimalkan jumlah pos pemadam kebakaran agar dapat mencakup seluruh wilayah yang telah ditentukan (Idayani et al., 2021).

Dalam menyelesaikan pemrograman linier, Taha (2017) mengatakan bahwa metode simpleks tidak menghitung semua solusi dasar (titik sudut) dari masalah pemrograman linier, tetapi hanya menyelidiki beberapa pilihan solusi (Taha, 2017). Oleh karena itu, dengan menggunakan metode simpleks, permasalahan pemrograman linier akan cepat terselesaikan. Optimasi menggunakan pemrograman linier untuk menentukan lokasi pos pemadam kebakaran dibahas dalam penelitian ini. Fungsi tujuannya adalah meminimalkan jumlah pos pemadam kebakaran dengan mempertimbangkan waktu tempuh menuju lokasi kebakaran. Model program liner integer yang dibentuk dengan data aktual dan diselesaikan menggunakan metode simpleks dengan bantuan software MPL (Mathematical Programming Language).

\section{METODE}

Hal pertama yang dilakukan dalam penelitian ini adalah studi literatur dengan tujuan mengetahui lebih dalam mengenai teori terkait pemrograman linier dan terapannya serta penyelesaiannya menggunakan metode simpleks. Studi literatur juga dilakukan untuk mengetahui bagaimana menyelesaikan pemrograman liner dengan menggunakan software MPL. Data yang digunakan diperoleh dari UPT Pemadam Kebakaran dan Penyelamatan Kabupaten Situbondo yang berupa dokumen Standar Operasional Prosedur (SOP) dan arsip data kebakaran. Teknik pengumpulan data yang dilakukan berupa metode wawancara dan dokumentasi. 
Setelah data diperoleh dilakukan pengolahan data dan pembentukan model optimasi menggunakan pemrograman linier. Kemudian diselesaikan menggunakan metode simpleks untuk mendapatkan solusi optimal berupa lokasi pos pemadam kebakaran. Pada tahap ini model optimasi berupa fungsi tujuan. Kemudian data yang diperoleh berupa asumsi waktu yang diperlukan untuk mencapai sembarang titik di kecamatan-kecamatan Kabupaten Situbondo ke titik lainnya yang digunakan sebagai fungsi kendala. Kemudian dilakukan penyelesaian menggunakan software MPL 5.0 untuk menemukan hasil fungsi optimal dari model optimasi lokasi pos pemadam kebakaran di Kabupaten Situbondo. Tahapan penelitian ditunjukkan dalam Gambar 1.

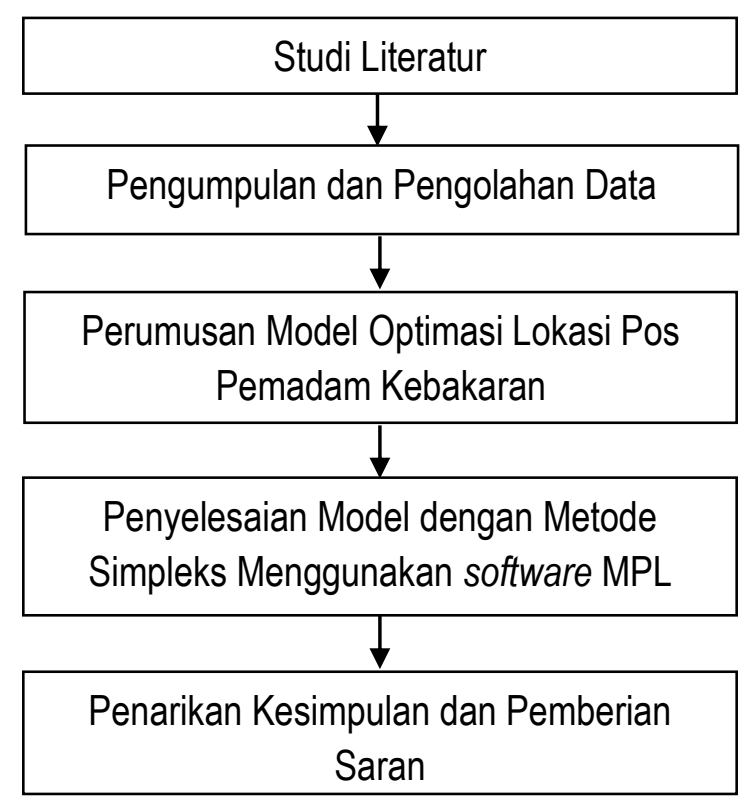

Gambar 1. Tahapan penelitian

\section{TINJAUAN PUSTAKA}

\section{Pemrograman Linier}

Pemrograman linier merupakan salah satu bagian dari riset operasi yang digunakan untuk memecahkan persoalan optimasi dengan menggunakan persamaan dan pertidaksamaan linier. Hu dan Kahng (2016) menyebutkan bahwa pemrograman linier dikembangkan pada abad ke-20 untuk menyelesaikan masalah sosial (Hu \& Kahng, 2016). Saat ini, pemrograman linier atau versi yang lebih umum disebut pemrograman matematika, telah terbukti berguna dalam berbagai bidang, seperti ekonomi, managemen, semua cabang teknik, fisika, kimia, dan bahkan matematika murni itu sendiri. Vanderbei (2020) dalam bukunya membuktikan teorema terkait pemrograman linier. Dalam teorema tersebut menyebutkan bahwa untuk pemrograman liner abitrer dalam bentuk standar, pernyataan berikut benar: (1) Jika tidak ada solusi optimal, maka masalahnya tidak layak atau tidak terbatas; (2) Jika solusi layak ada, maka solusi layak dasar ada; dan (3) Jika solusi optimal ada, maka solusi optimal dasar ada (Vanderbei, 2020).

Dalam pemrograman linier dicari penyelesaian yang optimal dengan memperhatikan batasan-batasan yang ada (Supranto, 1991). Dumairy (2012) menyebut batasan-batasan ini dengan istilah kendala. Menurut Dumairy, fungsi linier yang harus dipenuhi dalam mengoptimalkan fungsi 
tujuan dapat berbentuk persamaan maupun pertidaksamaan yang disebut kendala (Dumairy, 2012). Ada tiga unsur utama yang membangun pemrograman linier, yaitu variabel keputusan, fungsi tujuan, dan fungsi kendala (Siswanto, 2007). Variabel keputusan adalah yang akan ditentukan sebagai penyelesaian dengan fungsi tujuan yang akan dioptimalkan (minimal atau maksimal) dan kendalakendala sebagai kondisi atau syarat yang ada harus dipenuhi.

Fungsi tujuan yang diminimumkan dinotasikan dengan $F_{\min }$ dan relasi dalam kendala berbentuk $(\geq)$ sehingga menjadi:

Meminimumkan fungsi tujuan

$$
F_{\text {min }}=c_{1} x_{1}+c_{2} x_{2}+\cdots+c_{j} x_{j}
$$

dengan kendala

dan kendala non-negatif

$$
\begin{aligned}
& a_{11} x_{1}+a_{12} x_{2}+\cdots+a_{1 j} x_{j} \geq b_{1} \\
& a_{21} x_{1}+a_{22} x_{2}+\cdots+a_{2 j} x_{j} \geq b_{2} \\
& a_{i 1} x_{1}+a_{i 2} x_{2}+\cdots+a_{i j} x_{j} \geq b_{i}
\end{aligned}
$$

$$
x_{j} \geq 0(j=1,2, \ldots, n)
$$

dengan

$x_{j}$ : variabel keputusan ke-j $(j=1,2, \ldots, n)$

$b_{i}:$ konstanta pada kendala ke-i $(i=1,2, \ldots, m)$

$a_{i j}$ : koefisien variabel keputusan ke-j pada kendala ke-i

$c_{j}:$ koefisien variabel keputusan ke-j pada fungsi tujuan

\section{Metode Simpleks}

Pemrograman linier dapat diselesaikan dengan menggunakan cara grafik jika mempunyai dua variabel. Jika mempunyai lebih dari dua variabel tidak mungkin menggunakan cara grafik. Cara yang dapat digunakan adalah metode simpleks. Metode ini dapat digunakan untuk menyelesaikan pemrograman linier dengan dua variabel keputusan atau lebih.

Pemenang Nobel, Matematikawan Rusia, Leonid Kantorovich (1912-1986) dianggap sebagai penemu teori pemrograman linier. Tapi algoritma simpleks yang dikembangkan oleh Matematikawan Amerika Goerge B. Dantzig (1914-2005) membuat pemrograman linier dapat dipecahkan. Keberhasilan algoritma Dantzig ini mengantarkan pada perkembangan inovatif dalam area optimasi yang belum pernah dieksplorasi sebelumnya. Taha mengatakan bahwa daripada menghitung semua solusi dasar (titik sudut) dari masalah pemrograman linier, metode simpleks hanya menyelidiki beberapa pilihan solusi (Taha, 2017).

Metode simpleks didasarkan pada tiga prinsip penting: (1) Memungkinkan untuk menentukan paling tidak satu solusi yang diperbolehkan (rencana), yang sering disebut sebagai rencana dasar; (2) Memungkinkan untuk memeriksa apakah rencana dasar yang diperbolehkan optimal atau tidak; (3) Ada kemungkinan rencana tersebut tidak optimal, maka rencana yang lain dapat dipilih, yaitu yang paling mendekati optimal (Stanimirovic, 2022).

\section{MPL}

MPL adalah singkatan dari Mathematical Programming Language yang dikembangkan oleh Maximal Software. MPL adalah sistem pemodelan canggih yang memungkinkan pengguna model 
untuk merumuskan model optimasi yang rumit dengan cara yang jelas, ringkas, dan efisien. MPL menyediakan perumusan model permasalahan, mengumpulkan, dan memelihara data, mengoptimalkan model, dan kemudian mengumpulkan dan menganalisis hasilnya. Hasil solusi diambil secara otomatis dari solver dan ditampilkan secara rinci. MPL dirancang untuk menjadi perangkat lunak portable dan dapat dijalankan pada berbagai platform, salah satunya adalah Windows (Tim, 2020b).

\section{HASIL DAN PEMBAHASAN Model Optimasi}

Model optimasi dibentuk oleh fungsi tujuan untuk meminimalkan biaya dengan kendala waktu tempuh dan kendala non-negatif.

\section{Fungsi tujuan}

Fungsi tujuan dalam model program linier ini bertujuan untuk meminimalkan biaya dengan meminimalkan jumlah pos pemadam kebakaran. Berdasarkan data yang diperoleh dari UPT Pemadam Kebakaran Kabupaten Situbondo, jumlah kecamatan yang ada di Kabupaten Situbondo adalah 17 kecamatan, yang kemudian dibagi menjadi tiga koridor penanganan, yaitu koridor barat, koridor tengah, dan koridor timur seperti pada Tabel 1 . Setiap kecamatan dinotasikan dengan $x_{j}$ dengan $j=1,2,3, \ldots, 17$ yang merupakan urutan setiap kecamatan. Kecamatan dengan tanda *) merupakan letak pos pemadam kebakaran di Kabupaten Situbondo saat ini.

Tabel 1. Kecamatan di Kabupaten Situbondo

\begin{tabular}{lll}
\hline \multicolumn{1}{c}{ Koridor Barat } & \multicolumn{1}{c}{ Koridor Tengah } & \multicolumn{1}{c}{ Koridor Timur } \\
\hline Sumbermalang $\left(x_{1}\right)$ & Kendit $\left(x_{8}\right)$ & Arjasa $\left(x_{14}\right)$ \\
Jatibanteng $\left(x_{2}\right)$ & Panarukan $\left(x_{9}\right)$ & Jangkar $\left(x_{15}\right)$ \\
Banyuglugur $\left(x_{3}\right)$ & Situbondo $\left(x_{10}\right)$ & Asembagus ${ }^{*}\left(x_{16}\right)$ \\
Besuki $^{*}\left(x_{4}\right)$ & ${\text { Mangaran }\left(x_{11}\right)}$ & Banyuputih $\left(x_{17}\right)$ \\
Suboh $\left(x_{5}\right)$ & Panji $^{*}\left(x_{12}\right)$ & \\
Mlandingan $\left(x_{6}\right)$ & ${\text { Kapongan }\left(x_{13}\right)}$ & \\
Bungatan $\left(x_{7}\right)$ & & \\
\hline
\end{tabular}

Dari data kecamatan pada Tabel 1 diperoleh fungsi tujuan minimalisasi sebagai berikut:

$$
\begin{aligned}
\min z= & x_{1}+x_{2}+x_{3}+x_{4}+x_{5}+x_{6}+x_{7}+x_{8}+x_{9}+x_{10}+x_{11}+x_{12}+x_{13}+x_{14}+ \\
& x_{15}+x_{16}+x_{17}
\end{aligned}
$$

2. Kendala waktu tempuh

Kendala waktu tempuh diperoleh berdasarkan waktu tempuh rata-rata antar kecamatan di Kabupaten Situbondo yang ditunjukkan dalam Tabel 2. Berdasarkan data yang diperoleh dari UPT Pemadam Kebakaran dan Penyelamatan Kabupaten Situbondo waktu manajemen kebakaran yang digunakan sesuai dengan standar operasional prosedur yang telah diatur didalam SOP Penanganan Bencana Kebakaran Jawa Timur yakni waktu maksimal \pm 15 menit untuk bencana kebakaran rumah 
dan \pm 20 menit untuk bencana kebakaran lahan (Tim, 2019). Maka dalam penelitian ini diasumsikan bahwa:

a. Bencana kebakaran yang terjadi merupakan bencana kebakaran rumah, sehingga standar waktu maksimal yang digunakan adalah \pm 15 menit untuk menjangkau lokasi bencana kebakaran.

b. Jalan yang dilalui untuk menjangkau lokasi kejadian kebakaran diasumsikan lancar, bebas hambatan dan tidak mengalami kemacetan.

c. UPT Pemadam Kebakaran dan Penyelamatan memiliki akses jalan untuk menjangkau semua kecamatan di Kabupaten Situbondo yang dapat dilakukan dari sembarang kecamatan.

d. Bencana kebakaran yang terjadi tidak lebih dari satu kejadian dalam waktu bersamaan.

e. Pos pemadam kebakaran dapat menangani kebakaran yang terjadi di kecamatan tempat pos pemadam kebakaran berada dan di kecamatan terdekat.

f. Jarak tempuh yang dilalui untuk menuju lokasi kejadian kebakaran diasumsikan dengan kecepatan yang stabil tanpa ada penurunan kecepatan.

Tabel 2. Waktu Rata-Rata Untuk Menjangkau Kecamatan-Kecamatan di Kabupaten Situbondo

\begin{tabular}{|l|l|l|l|l|l|l|l|l|l|l|l|l|l|l|l|l|l|}
\hline & $x_{1}$ & $x_{2}$ & $x_{3}$ & $x_{4}$ & $x_{5}$ & $x_{6}$ & $x_{7}$ & $x_{8}$ & $x_{9}$ & $x_{10}$ & $x_{11}$ & $x_{12}$ & $x_{13}$ & $x_{14}$ & $x_{15}$ & $x_{16}$ & $x_{17}$ \\
\hline$x_{1}$ & 0 & 5 & 10 & 10 & 10 & 15 & 15 & 20 & 25 & 25 & 30 & 30 & 32 & 35 & 37 & 40 & 45 \\
\hline$x_{2}$ & 5 & 0 & 5 & 5 & 5 & 10 & 10 & 15 & 20 & 20 & 25 & 25 & 27 & 30 & 32 & 35 & 40 \\
\hline$x_{3}$ & 10 & 5 & 0 & 5 & 10 & 15 & 15 & 20 & 20 & 25 & 30 & 30 & 32 & 35 & 37 & 40 & 45 \\
\hline$x_{4}$ & 10 & 5 & 5 & 0 & 5 & 10 & 10 & 15 & 15 & 20 & 25 & 25 & 27 & 30 & 32 & 35 & 40 \\
\hline$x_{5}$ & 10 & 5 & 10 & 5 & 0 & 5 & 10 & 15 & 20 & 20 & 25 & 25 & 27 & 30 & 32 & 35 & 40 \\
\hline$x_{6}$ & 15 & 10 & 15 & 10 & 5 & 0 & 5 & 5 & 10 & 10 & 15 & 15 & 17 & 20 & 22 & 25 & 30 \\
\hline$x_{7}$ & 15 & 10 & 15 & 10 & 10 & 5 & 0 & 5 & 10 & 10 & 15 & 15 & 17 & 20 & 22 & 25 & 30 \\
\hline$x_{8}$ & 20 & 15 & 20 & 15 & 15 & 5 & 5 & 0 & 5 & 5 & 10 & 10 & 12 & 15 & 17 & 20 & 25 \\
\hline$x_{9}$ & 25 & 20 & 20 & 15 & 20 & 10 & 10 & 5 & 0 & 5 & 10 & 10 & 12 & 15 & 17 & 20 & 25 \\
\hline$x_{10}$ & 25 & 20 & 25 & 20 & 20 & 10 & 10 & 5 & 5 & 0 & 5 & 5 & 7 & 10 & 17 & 20 & 25 \\
\hline$x_{11}$ & 30 & 25 & 30 & 25 & 25 & 15 & 15 & 10 & 10 & 5 & 0 & 5 & 5 & 10 & 17 & 20 & 25 \\
\hline$x_{12}$ & 30 & 25 & 30 & 25 & 25 & 15 & 15 & 10 & 10 & 5 & 5 & 0 & 2 & 5 & 7 & 10 & 25 \\
\hline$x_{13}$ & 32 & 27 & 32 & 27 & 27 & 17 & 17 & 12 & 12 & 7 & 5 & 2 & 0 & 5 & 7 & 10 & 20 \\
\hline$x_{14}$ & 35 & 30 & 35 & 30 & 30 & 20 & 20 & 15 & 15 & 10 & 10 & 5 & 5 & 0 & 2 & 8 & 17 \\
\hline$x_{15}$ & 37 & 32 & 37 & 32 & 32 & 22 & 22 & 17 & 17 & 17 & 17 & 7 & 7 & 2 & 0 & 5 & 15 \\
\hline$x_{16}$ & 40 & 35 & 40 & 35 & 35 & 25 & 25 & 20 & 20 & 20 & 20 & 10 & 10 & 8 & 5 & 0 & 10 \\
\hline$x_{17}$ & 45 & 40 & 45 & 40 & 40 & 30 & 30 & 25 & 25 & 25 & 25 & 20 & 17 & 15 & 10 & 5 & 0 \\
\hline
\end{tabular}

Koefisien pada kendala waktu tempuh ditentukan berdasarkan asumsi syarat waktu tempuh rata-rata yang dibutuhkan yaitu \pm 15 menit. Jika waktu tempuh antara satu kecamatan dengan kecamatan yang lain kurang atau sama dengan 15 menit, maka akan ada kemungkinan dibangun pos pemadam kebakaran baru yang berarti koefisiennya 1. Sebaliknya, jika lebih dari 15 menit maka tidak akan dibangun pos baru sehingga koefisiennya 0 . Ruas kanan dalam kendala ini harus bernilai positif dan lebih dari atau sama dengan satu, karena mewakili jumlah pos pemadam kebakaran dalam satu jalur tempuh. Dari Tabel 2 terbentuk sebanyak 17 pertidaksamaan. Namun terdapat 4 pertidaksamaan yang sama, sehingga hanya ada 13 pertidaksamaan yang merupakan kendala 
waktu tempuh. Jadi dari data waktu tempuh pada Tabel 2 diperoleh kendala waktu tempuh sebagai berikut.

$$
\begin{array}{rr}
x_{1}+x_{2}+x_{3}+x_{4}+x_{5}+x_{6}+x_{7} & \geq 1 \\
x_{1}+x_{2}+x_{3}+x_{4}+x_{5}+x_{6}+x_{7}+x_{8} & \geq 1 \\
x_{1}+x_{2}+x_{3}+x_{4}+x_{5}+x_{6}+x_{7}+x_{8}+x_{9} & \geq 1 \\
x_{1}+x_{2}+x_{3}+x_{4}+x_{5}+x_{6}+x_{7}+x_{8}+x_{9}+x_{10}+x_{11}+x_{12} & \geq 1 \\
x_{2}+\quad x_{4}+x_{5}+x_{6}+x_{7}+x_{8}+x_{9}+x_{10}+x_{11}+x_{12}+x_{13}+x_{14} & \geq 1 \\
x_{4}+\quad x_{6}+x_{7}+x_{8}+x_{9}+x_{10}+x_{11}+x_{12}+x_{13}+x_{14} & \geq 1 \\
x_{6}+x_{7}+x_{8}+x_{9}+x_{10}+x_{11}+x_{12}+x_{13}+x_{14}+x_{15} & \geq 1 \\
x_{6}+x_{7}+x_{8}+x_{9}+x_{10}+x_{11}+x_{12}+x_{13}+x_{14} & \geq 1 \\
x_{6}+x_{7}+x_{8}+x_{9}+x_{10}+x_{11}+x_{12}+x_{13}+x_{14}+x_{15}+x_{16} & \geq 1 \\
x_{8}+x_{9}+x_{10}+x_{11}+x_{12}+x_{13}+x_{14}+x_{15}+x_{16} & \geq 1 \\
x_{8}+x_{9}+x_{10}+x_{11}+x_{12}+x_{13}+x_{14}+x_{15}+x_{16}+x_{17} & \geq 1 \\
x_{12}+x_{13}+x_{14}+x_{15}+x_{16}+x_{17} & \geq 1 \\
x_{13}+x_{14}+x_{15}+x_{16}+x_{17} & \geq 1
\end{array}
$$

3. Kendala non-negatif

Dengan adanya kendala non-negatif untuk semua variabel $x_{1}, x_{2}, x_{3}, \ldots$, dan $x_{17}$ menjamin variabel-variabel tersebut bernilai 0 atau positif. Hal tersebut diperlukan karena variabe-variabel tersebut merepresentasikan jumlah pos pemadam kebakaran di setiap kecamatan yang tidak mungkin bernilai negatif. Jadi kendalah non-negatifnya adalah

$$
x_{1}, x_{2}, x_{3}, \ldots, x_{17} \geq 0
$$

\section{Penyelesaian Optimal Menggunakan Software MPL}

Penyelesaian masalah program linier dengan metode simpleks dalam penelitian ini diperoleh dengan menggunakan software MPL 5.0 dalam waktu 0,03 detik dengan 8 iterasi. Solver yang digunakan adalah Lindo yang merupakan solver yang mendukung algoritma pemrograman liner, pemrograman non-linier, pemrograman linier bilangan bulat campur (mix integer linear programming), dll (Tim, 2020a).

Output dari MPL ditunjukkan pada Gambar 2 dan Gambar 3. Gambar 2 menunjukkan output fungsi objektif (objective value) $z_{\min }=2$. Gambar 3 menunjukkan output variabel keputusan (decision variables) yaitu lokasi pos pemadam kebakaran yang optimal $x_{3}=x_{14}=1$. Hasil tersebut menyatakan bahwa lokasi pos pemadam kebakaran sebaiknya dibangun di dua lokasi, yaitu di Kecamatan Banyuglugur yang berada di Situbondo bagian barat dan Kecamatan Arjasa yang berada di Situbondo bagian timur. Hasil ini sesuai dengan bentuk geografis Kabupaten Situbondo yang memanjang dari arah barat ke timur. 


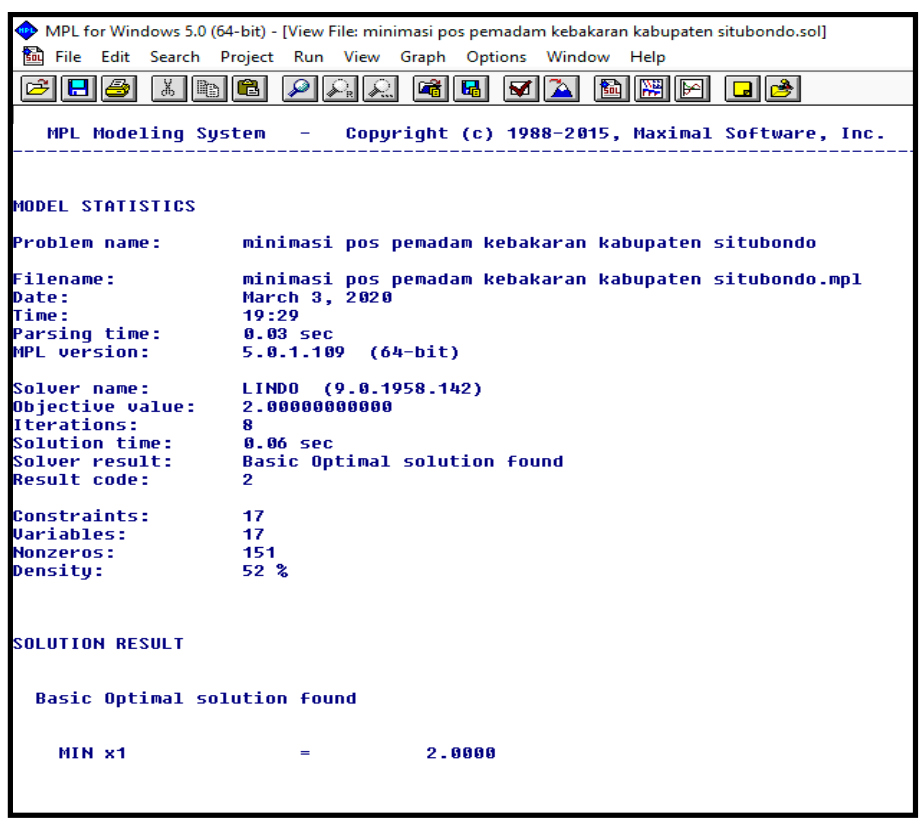

Gambar 2. Output fungsi tujuan (objective value)

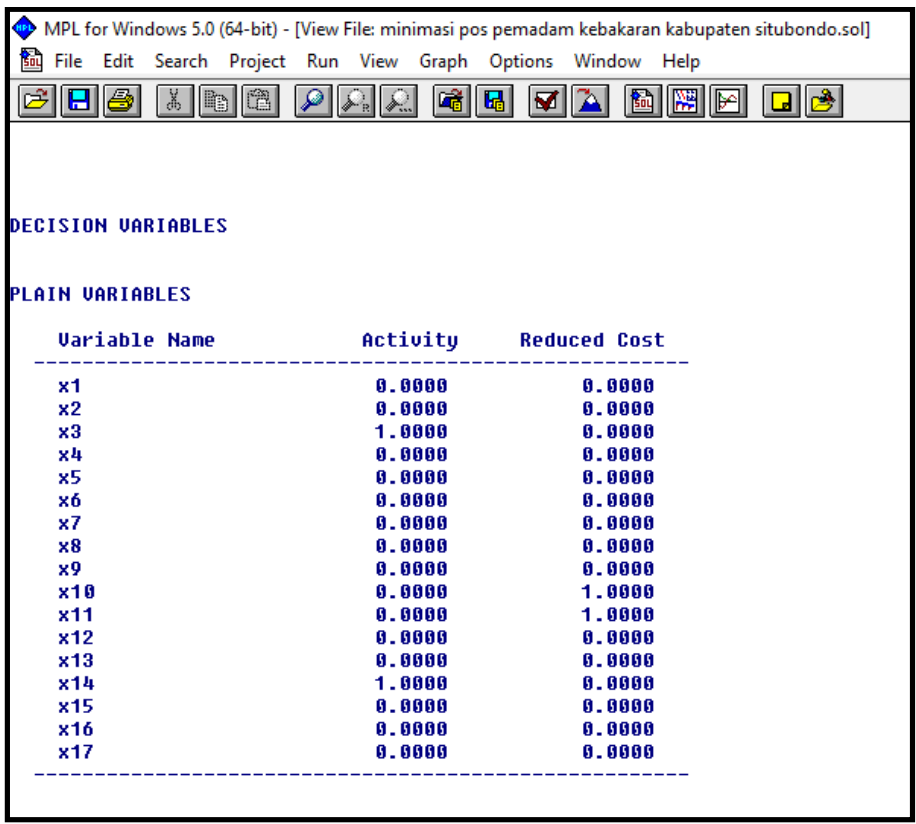

\section{Gambar 3. Output variabel keputusan/lokasi pos pemadam kebakaran (decision variables)}

Jika dibandingkan dengan lokasi pos pemadam kebakaran saat ini yang berada di 3 kecamatan, yaitu Besuki, Panji, dan Asembagus dengan $z_{\min }=3$ solusi yang ditawarkan membutuhkan biaya lebih kecil sehingga dapat dikatakan lebih optimal. Walaupun biayanya lebih 
sedikit tetapi dapat menjamin keterjangkauan ke seluruh wilayah Kabupaten Situbondo karena telah memenuhi kendala waktu tempuh.

\section{SIMPULAN}

Simpulan dari penelitian ini adalah pemrograman linier dapat digunakan untuk menyelesaikan permasalahan pemilihan lokasi pos pemadam kebakaran. Berdasarkan hasil dan pembahasan, lokasi optimal pos pemadam kebakaran terletak di Kecamatan Banyuglugur dan Kecamatan Arjasa.

Saran untuk penelitian selanjutnya dapat dikembangkan model pemrograman linier dengan menambahkan kendala seperti volume kendaraan atau kepadatan lalu lintas, aksesibilitas jalan, kecepatan kendaraan pemadam kebakaran yang terdapat di Kabupaten Situbondo yang dapat mempengaruhi kinerja kebakaran pemadam kebakaran.

\section{REFERENSI}

Dumairy. (2012). Matematika Terapan untuk Bisnis dan Ekonomi (Edisi 2). BPFE.

Febrianto, I., \& Siswanto, N. (2020). Mixed Integer Linear Programming as a Method for Evaluation of Location and Number of Buffer Warehouse in PT Petrokimia Gresik Distribution System (Case Study: West Java and Central Java). IPTEK Journal of Proceedings Series, 3, 104109.

Hasan, M. M., \& Kadhim, I. J. (2020). The Efficiency of Using the Mixed Model of Fuzzy and Integer Programming in Selecting the Optimal Location for Emergent Health Services in Najaf City. International Journal of Innovation, Creativity and Change, 14(7), 831-842. https://doi.org/10.13140/RG.2.2.25595.34085.

Hu, T. C., \& Kahng, A. B. (2016). Linear and Integer Programming Made Easy. Springer International Publishing. https://doi.org/10.1007/978-3-319-24001-5.

Idayani, D., Puspitasari, Y., \& Sari, L. D. K. (2020). Penggunaan Model Set Covering Problem dalam Penentuan Lokasi dan Jumlah Pos Pemadam Kebakaran. Soulmath, 8(2), 139-152. https://doi.org/10.25139/smi.v8i2.3280.

Idayani, D., Puspitasari, Y., \& Sari, L. D. K. (2021). Maximal Covering Problem Model for Determination of Fire Station Location. Proceedings of the International Conference on Innovation in Science and Technology (ICIST 2020), 208(Advanced in Engineering Research), 20-23. https://doi.org/10.2991/aer.k.211129.005.

Jasriadi, Iriana, R. T., \& Djuniati, S. (2015). Analisis Lokasi dan Jumlah Stasiun Pemadam Kebakaran Kota Pekanbaru. Jom FTEKNIK, 2(1), 1-10.

Siswanto. (2007). Operation Research. Erlangga.

Stanimirovic, I. (2022). Advances in Optimization and Linear Programming. Apple Academic Press, Inc.

Supranto, J. (1991). Teknik Pengambilan Keputusan. Rineka Cipta.

Taha, H. A. (2017). Operations Research: An Introduction, 10th Edition. Pearson Education Limited. Tim. (2019). SOP Penanganan Saat Terjadi Kebakaran. UPT Pemadam Kebakaran dan Penyelamatan Kabupaten Situbondo. 
Tim. (2020a). LINDO for MPL. Maximal Software, Inc. http://www.maximalsoftware.com/solvers/ lindo.html. Diakses 5 Juni 2020.

Tim. (2020b). MPL Modeling System. Maximal Software, Inc. http://www.maximalsoftware.com/mpl/ . Diakses 29 Maret 2020.

Vanderbei, R. J. (2020). Linear Programming: Foundations and Extentions (Fifth Ed.). Springer Nature. https://doi.org/10.1007/978-3-030-39415-8. 